\title{
Analysis of Closed Loop Production System using Orthogonal Array and Integer Programming Optimization
}

\author{
ABDUL SALAM KHAN* \\ RECEIVED ON 05.06.2018 ACCEPTED ON 17.08.2018 \\ ABSTRACT
}

Sustainable production systems require optimal utilization of resources. Raw material acquisition is one of the costly processes in a production system. EOL (End-of-Life) products re-manufacturing through reverse logistics can help in decreasing excessive raw material cost. In this study, we consider production system of closed loop supply chain in which both forward and reverse production systems are active. DOE (Design of Experiments) methodology is incorporated which is a statistical approach adopted in dealing with complex workplace problems. We employ $L_{9}$ orthogonal array using Taguchi experiment in Minitab 17 and DOE for plotting the results. Dependent variables used in this study are productivity, $P$ (number of forward and reverse products produced per period) and quality accuracy of product (measured in percent deviation from reference standards). A trade-off analysis between the control variables is presented on the basis of SNR (Signal to Noise Ratio). Control variables used in the analysis are tools employed in production system (tu), number of machines being used (m) and dedicated manufacturing cells (dc). We use three levels of analysis for each control factor. Optimum result conditions are calculated using signal to noise ratio with larger-the-better-criteria as well as smaller-the-better criteria and study is concluded with main effects of the mean plots. DOE optimization analysis for productivity suggests combination set of 32, 8, and 6 for tools, machines in use and manufacturing cells, respectively. Similarly, for optimal dimensional accuracy, tools used are 24; number of machines in use is 14 with 3 manufacturing cells. All result indices are accomplished within a confidence interval of $95 \%$ with p-values less than 0.05. MILP (Mixed Integer Linear Programming) analysis considers cost function of production and transportation between tools, machines and levels and Taguchi based experimental findings are validated by mathematical optimization findings.

Key Words: Closed Loop Supply Chain, Design of Experiments, Productivity, Taguchi Experiment, Design Experts, Signal to Noise Ration.

\section{INTRODUCTION}

$\mathrm{P}$ roduction systems are faced with enormous business challenges where resource efficient utilization and cost minimization are more prominent. Resources of production system include raw materials, energy, technology, tools and manpower. If resources are optimally utilized, then cost minimization can be accomplished. Different strategies in production systems are opted for optimal utilization 
of resources such as batch-sizing, work in process quality inspection and leagile practices [1]. Due to competitive market dynamics, cost optimality is of no use if it comes as a result of compromise on quality. In this article, we discuss one of the efficient ways to optimally use resources in the form of raw material usage by considering case of a CLSC (Closed Loop Supply Chain). CLSC is an alternative and modernized way to look at SC (Supply Chain) issues in a way that product liability rests upon the production system for its entire life cycle [2]. SC involves multiple business activities such as acquisition of raw materials, production, logistics management and distribution of the product to customer [3]. A normal SC moves the product line in one direction starting from accessing raw material from supplier and delivery to the end customer; however, in CLSC, both forward and reverse movements of the product (to and fro from the customer) are considered. CLSC is implemented to moderate the economic and environmental consequences of the products; for instance, minimization of products containing Carbon contents (environmental degradation) [4]. CLSC is defined as "design, control and operation of a system to maximize value creation over the entire life cycle of a product with dynamic recovery of value from different types and volumes of returns over time" [5]. Reverse logistics deal with collection of products from customer once they serve their useful life which is quite opposite to the traditional logistic services [6].

Reverse logistic operations have created more hype in the wake of corporate social responsibility [7] and it is one of the leading practices adopted by giants such as BMW, Howard Packard and General Motors [8]. CLSC containing both forward and reverse logistics brings about phenomenal advantages to the business such as green design and manufacturing, product life cycle assessment, waste management and formation of sustainable and eco-friendly environment [9]. Forward loop of CLSC is more stagnant and predictable in a sense that an orthodox method is followed for processing a product on assembly line. However, in the case of reverse logistics, it is hard to identify that product would retrieve back into the system at what point. For instance, reversed product might need repair, recondition, re-manufacturing and/or recycling depending upon the state of the product as shown in Fig.1 [10]. If repair is needed, product would pass through post-assembling facility where minor adjustments are provided and if it is to be reconditioned, it is fed into the assembly line. This makes the process more uncertain for balancing between the forward and reverse assembly line. Similarly, an evaluation needs to be performed for the assessment of productivity of the CLSC and quality of the products being produced.

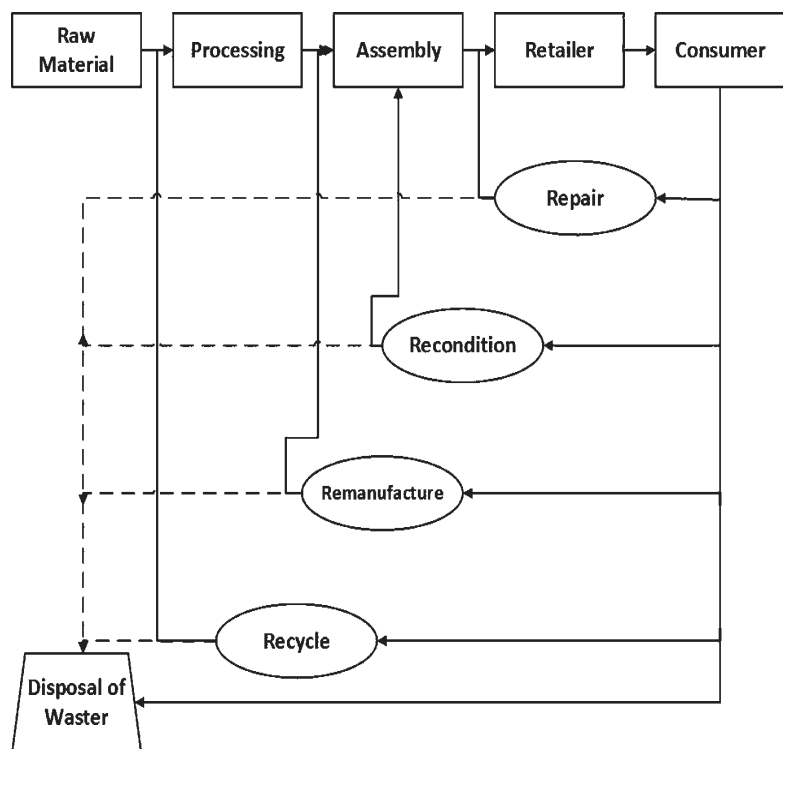

FIG. 1. SCHEMATIC OF CLOSED LOOP SUPPLY CHAIN [10]

Mehran University Research Journal of Engineering \& Technology, Volume 38, No. 3, July, 2019 [p-ISSN: 0254-7821, e-ISSN: 2413-7219] 
Reverse logistics provides with efficient centralized system for controlling, implementing and planning in accordance with requirements of the production system [11]. To re-emphasize, it is not necessary that the product through reverse chain enters into the system from the start but rather it can enter into the production system at any point depending upon the condition of the product and services/processes needed to be performed. RL (Reverse Logistics) serves for extracting value from the collected items and thus it follows start to a new SC [12], which in connection to the existing SC creates problems such as productivity, quality of production, work scheduling and demand completion [13-14]. RL extends the vision of production system and SC management by triggering more confounding factors into consideration [15]. Both forward and reverse logistics form closed loop supply chain which is a sustainable approach for managing and recovering end of life products [16]. In the past two decades, closed loop supply chain in general and reverse logistics in particular has been focus of research attention in the academic arena [17]. From operational research viewpoint, much attention is provided to economic aspects [18-20], environmental footprints [21-23] and performance analysis [24-25] of reverse logistics. Most of the performance analysis studies are centered on remanufacturing optimization with an assembly line approach [26]; however, reverse logistics is a time varying phenomena [27] for which production system is urged to react in a dynamic manner. Production system needs to be aligned with flexibility to cope with the manufacturing requirements of both forward and reverse items. This requires combination of resources to optimize the efforts in meeting customers' requirements as well as profitability concerns. In the larger context, RL affects quality of products and productivity ofproduction system along with other variables [28]. In research literature of $\mathrm{RL}$, in house production resources optimization for production of both streams (forward and reverse) is still unexplored. This study contributes to the literature of reverse logistics by suggesting optimal combination of tools, machines and cells used in the manufacturing assembly line of a CLSC in order to optimize productivity and dimensional accuracy. We address the following research question: "In CLSC. What is the optimal number of tools, machines and manufacturing cells employed in the production system to enhance productivity and quality of production system?" In order to analyze the quality and productivity of a reverse logistics, Taguchi method is employed for examining the closed loop supply chain. In the next section, methodology of the study is outlined.

\section{METHODOLOGY}

We analyze manufacturing line of CLSC using Taguchi method which is a statistical robust technique for process parameters examination. Taguchi method has been in practice for more than 3 decades now and its utility can be found in contexts such as manufacturing, process design and SC [29]. Taguchi method is used in diverse range of reverse logistics problems such as polyethylene bottles [30], in the context of uncertain pricing of used products [31], for environmental consideration [32] and reverse logistics network design [33]. Taguchi method starts with identification of the study control variables and their salience, followed by selection of noise factors (factors which are un-controllable). In the third step we define the objective function and explicate the levels of control factors. On the basis of levels of identified factors, orthogonal array is constructed for experimentation and validation purposes [34]. Fig. 2 shows the flow diagram of the process. 
For analysis of the study, we considered a French manufacturing assembly line of automotive engines and performed statistical analysis of parts in high need of repair and replacement through reverse logistics. We considered three parts for the study investigation which were; Piston, Case and Connecting rod as shown in Fig. 3.

\section{EXPERIMENT DESIGN}

As a result of both forward and reverse channeling; enterprise wanted to investigate effect on their

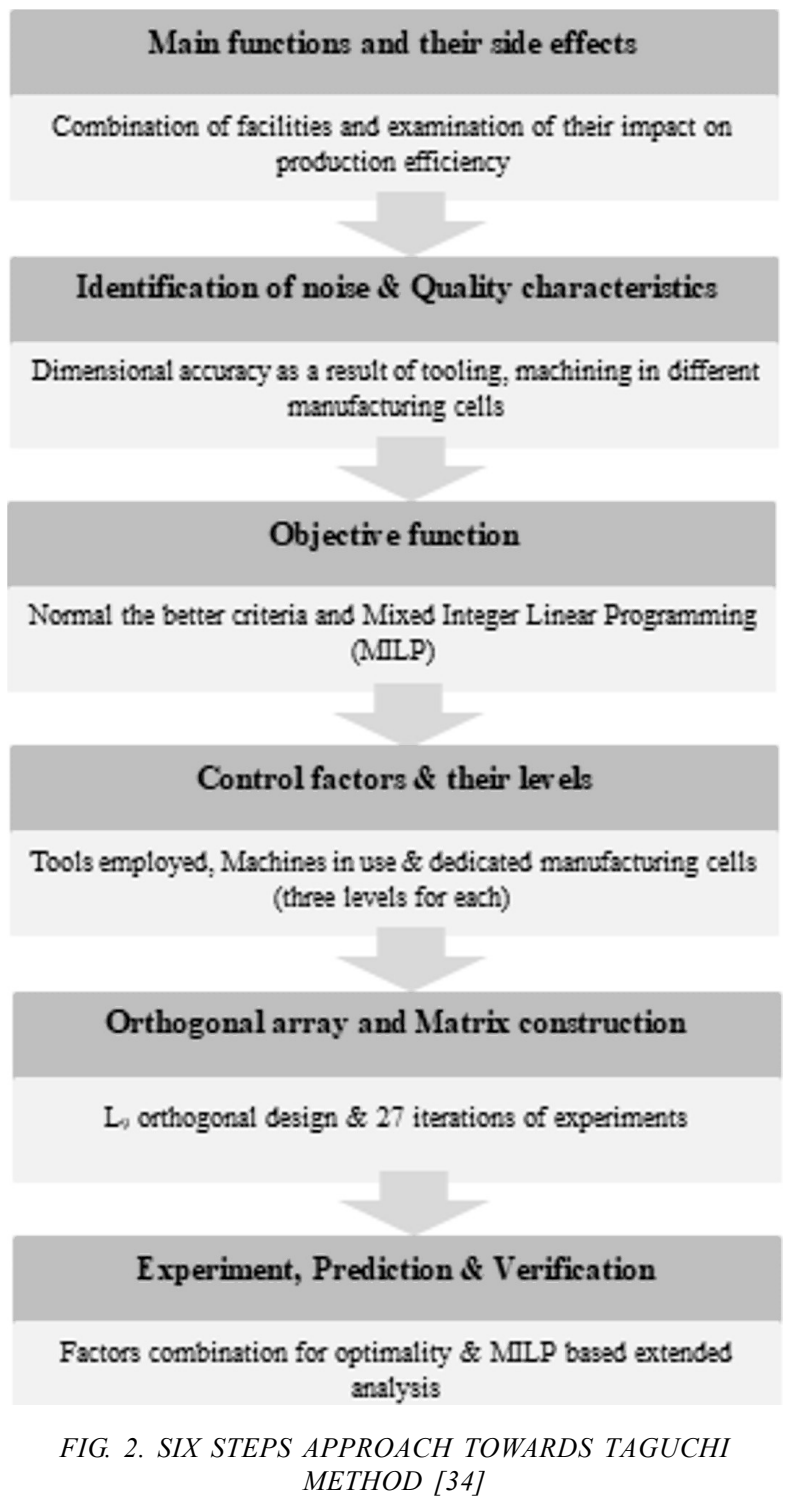

productivity and quality of the product produced. A cellular layout was designed in the assembly line for dedicated manufacturing cells indulged in the closed loop production. We considered three control factors and two noise factors (un-controlled and study variables) for the study. Control factors were Tools employed, tu in the production process, machines in use, $m$ and dedicated manufacturing cells, dc while noise factors were productivity $\mathrm{P}$ and dimensional accuracy da. Productivity in this context is defined as number of products assembly line is producing in both forward and reverse logistics (in numbers) while dimensional accuracy is defined in terms of deviation of overall dimensions from the specified standards and it is measured in percentage (Table 1).

Next, we identify three levels for the selected control factors. For tool employment, number of tools varies from 24-38 in different machines. Similarly, 24 machines are used in level 1, 32 in level 2 while 38 in third level. Lastly, machines are designated to manufacturing cells such that 3 machines are in level 1, 6 machines are in level 2 while 11 machines are assigned to level 3 (Table 2).

Table 3 contains list of nine (9) experiments and combination of independent/control factors level in that particular experiment. Similarly, in Table 4, values of control variables are provided for particular experiments. For instance, from Table 3 we understand that experiment 7 contains level 3 value for tools, level 1 value for machines used while level 3 value manufacturing cells which are translated as 38 tools, 8 machines and 11 manufacturing cells (from Table 4).

Taguchi method full factorial orthogonal array is applied for analysis purposes. Since we had 3 control factors, we applied $\mathrm{L}_{9}$ orthogonal array with three runs on each 
experiment, making in total 27 iterations of the experiments. Taguchi can be used for analysis of SNR with one of the three performance characteristic; Larger the better, Smaller the better and Nominal the better. Larger the better is a performance characteristic used when the desire is to maximize the value of outcome (productivity in this case) while smaller the better indicator is used for minimization of the outcome, i.e., dimensional deviation in this case.
The formula for both larger the better and smaller the better are given below.

Larger the better

$$
\mathrm{S} / \mathrm{N}=-10 \log \left(\frac{1}{\mathrm{n}} \times \sum_{\mathrm{i}=1}^{\mathrm{n}} \mathrm{y}_{\mathrm{i}}^{2}\right)
$$

Where $\mathrm{N}=$ number of iterations/experiments and $\mathrm{Y}_{\mathrm{i}}=$ control factor $\mathrm{i}$

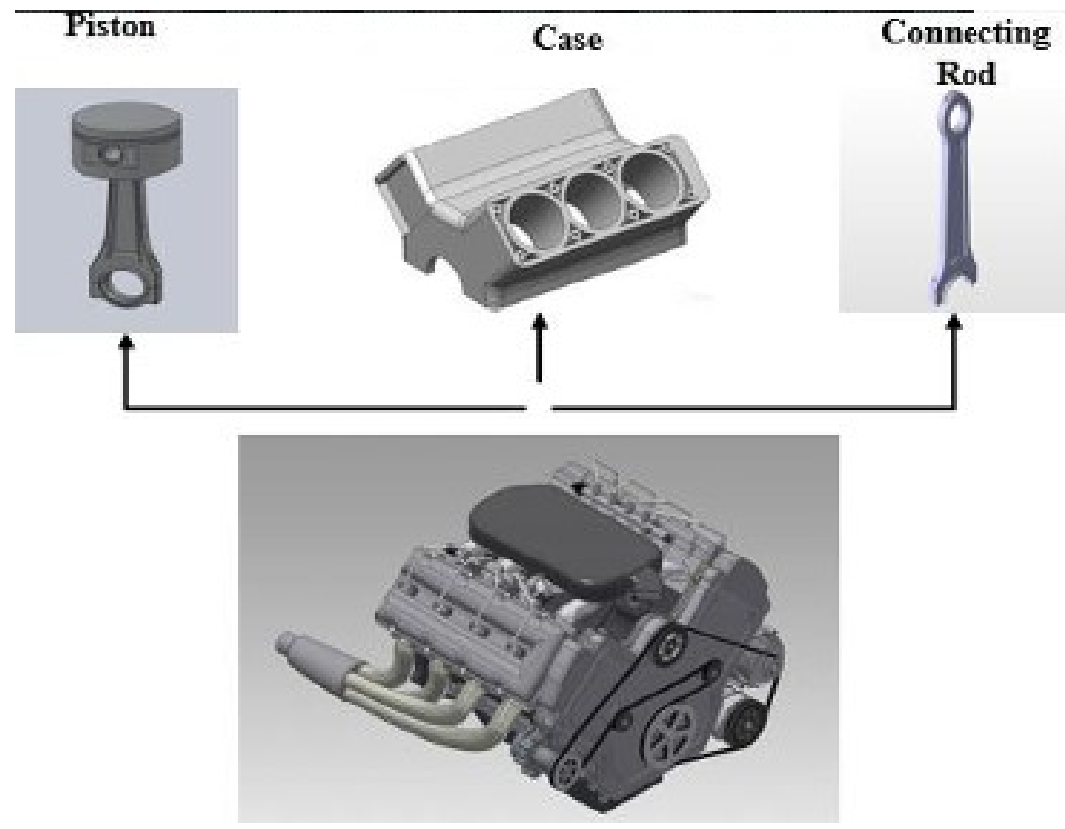

FIG. 3. SELECTION OF PARTS FOR STUDY ANALYSIS

TABLE 1. LIST OF CONTROL AND NOISE FACTORS CONSIDERED FOR THE STUDY ANALYSIS

\begin{tabular}{|c|c|}
\hline Control Factor & Noise Factor \\
\cline { 1 - 2 } Tools Employed (tu) & \\
\cline { 1 - 2 } Machines in Use (m) & $\begin{array}{c}\text { Productivity (Production in a Period) (P) } \\
\text { Dimensional accuracy (da) }\end{array}$ \\
\hline Dedicated Manufacturing Cells (dc) & \\
\hline
\end{tabular}

TABLE 2. FACTORS AND THEIR THREE LEVELS

\begin{tabular}{|c|c|c|c|}
\hline \multirow{2}{*}{ Factors } & \multicolumn{3}{|c|}{ Levels } \\
\cline { 2 - 4 } & 1 & 2 & 3 \\
\hline Tools Employed (tu) & 24 & 32 & 38 \\
\hline Machines in Use (m) & 8 & 14 & 22 \\
\hline Dedicated Manufacturing Cells (dc) & 3 & 6 & 11 \\
\hline
\end{tabular}

Mehran University Research Journal of Engineering \& Technology, Volume 38, No. 3, July, 2019 [p-ISSN: 0254-7821, e-ISSN: 2413-7219] 
Smaller the better

$\eta=-10 \log (\mathrm{MSD})$

Where $\mathrm{MSD}=($ Mean Square Deviation $)$ of control factor value in experiment $i$.

As mentioned in Table 5, total of 27 experiment runs were performed for analysis of productivity with the mean values also tabulated. Against the mean values, SNR is also provided and since we prefer higher productivity, we will select on the basis of larger the better criteria.

Next, we analyze data for our second non-controllable variable which is dimensional accuracy. Dimensional accuracy in this case is defined in terms of deviation of overall dimensions from standard specifications. It is expressed in terms of percentage and smaller the value of deviation (da), the better it is. SNR criteria of smaller the better is considered and Table 6 exhibits deviation values for all 27 experiments with mean value and SNR.

TABLE 3. NUMBER OF EXPERIMENTS AND COMBINATION OF THE FACTORS

\begin{tabular}{|c|c|c|c|}
\hline \multirow{2}{*}{ Experiments } & \multicolumn{2}{|c|}{ Factors } & 3 \\
\cline { 2 - 4 } & 1 & 2 & 1 \\
\hline 1 & 1 & 2 & 1 \\
\hline 2 & 1 & 3 & 1 \\
\hline 3 & 1 & 1 & 2 \\
\hline 4 & 2 & 2 & 2 \\
\hline 5 & 2 & 3 & 3 \\
\hline 6 & 2 & 1 & 3 \\
\hline 7 & 3 & 2 & 3 \\
\hline
\end{tabular}

TABLE 4. CONTROL FACTORS VALUES IN ALL 9 DEDICATE

\begin{tabular}{|c|c|c|c|}
\hline No. & Tools Employed (tu) & Machines in Use (m) & Manufacturing Cells (dc) \\
\hline 1 & 24 & 8 & 3 \\
\hline 2 & 24 & 22 & 3 \\
\hline 3 & 24 & 8 & 6 \\
\hline 4 & 32 & 14 & 6 \\
\hline 5 & 32 & 22 & 6 \\
\hline 6 & 32 & 8 & 11 \\
\hline 7 & 38 & 14 & 11 \\
\hline 8 & 38 & 22 & 11 \\
\hline
\end{tabular}

Mehran University Research Journal of Engineering \& Technology, Volume 38, No. 3, July, 2019 [p-ISSN: 0254-7821, e-ISSN: 2413-7219] 
In Table 7 sum and average of SNR for all control variables is presented for productivity factor and the same is depicted in Fig. 4.

As can be seen in Table 8, ANOVA (Analysis of Variance) test run results of control factors for both productivity and dimensional accuracy are significant at different levels. For Productivity, tools employed factor has a significance value of 0.04 , for machines factor the value is 0.019 while it is 0.036 for manufacturing cells. Similarly, in the case of Dimensional Accuracy, p-values are 0.022, 0.039 and 0.005 for tools, machines and cells, respectively. Overall, the results were significant within the bound of $95 \%$ confidence interval.

TABLE 5. TWENTY SEVEN (27) ITERATIONS FOR PRODUCTIVITY AND S/N RATIO ERIMENTS

\begin{tabular}{|c|c|c|c|c|c|}
\hline \multirow{2}{*}{ No. } & \multicolumn{4}{|c|}{ Productivity $(\mathrm{P})$} & \multirow{2}{*}{ SNR } \\
\hline & 1 & 2 & 3 & Mean & \\
\hline 1. & 70 & 64 & 67 & 67 & 27.36 \\
\hline 2. & 64 & 62 & 56 & 60.7 & 25.79 \\
\hline 3. & 72 & 70 & 74 & 72 & 28.42 \\
\hline 4. & 78 & 82 & 81 & 80.3 & 28.76 \\
\hline 5. & 62 & 66 & 67 & 65 & 26.90 \\
\hline 6. & 72 & 75 & 69 & 72 & 28.42 \\
\hline 7. & 70 & 67 & 70 & 69 & 27.88 \\
\hline 8. & 62 & 64 & 61 & 62.3 & 24.16 \\
\hline 9. & 62 & 58 & 60 & 60 & 23.56 \\
\hline
\end{tabular}

TABLE 6. TWENTY SEVEN (27) ITERATIONS FOR PRODUCTIVITY AND SNR

\begin{tabular}{|c|c|c|c|c|c|}
\hline \multirow{2}{*}{ No. } & \multicolumn{4}{|c|}{ Dimensional Accuracy (da) } & \multirow{2}{*}{ SNR } \\
\hline & 1. & 1.5 & 2 & Mean & \\
\hline 1. & 1.5 & 2 & 1.2 & 1.57 & -9.27 \\
\hline 2. & 1 & 1.5 & 1 & 1.16 & -6.82 \\
\hline 3. & 1.2 & 1 & 1.5 & 1.23 & -11.58 \\
\hline 4. & 1.5 & 1 & 2 & 1.50 & -9.04 \\
\hline 5. & 2.5 & 2 & 1 & 1.83 & -14.92 \\
\hline 6. & 1 & 2 & 2.5 & 1.83 & -14.92 \\
\hline 7. & 1.5 & 2.5 & 2.5 & 2.16 & -17.27 \\
\hline 8. & 2 & 2.5 & 1 & 1.83 & -14.92 \\
\hline 9. & 2.5 & 2.5 & 1 & 2.00 & -19.03 \\
\hline
\end{tabular}

Mehran University Research Journal of Engineering \& Technology, Volume 38, No. 3, July, 2019 [p-ISSN: 0254-7821, e-ISSN: 2413-7219] 
TABLE 7. SUM AND AVERAGE OF THREE LEVELS FOR CONTROL FACTORS

\begin{tabular}{|c|c|c|c|c|c|c|}
\hline \multirow{2}{*}{ Level } & \multicolumn{2}{|c|}{ Tools Employed (tu) } & \multicolumn{2}{c|}{ Machines in Use (m) } & \multicolumn{2}{c|}{ Manufacturing Cells (dc) } \\
\cline { 2 - 7 } & Sum & Average & Sum & Average & \multicolumn{2}{c|}{ Sum } \\
\hline 1 & 78.56 & 26.18 & 76.66 & 25.55 & 73.32 & 24.44 \\
\hline 2 & 75.89 & 25.29 & 74.32 & 24.80 & 74.86 & 24.95 \\
\hline 3 & 76.62 & 25.54 & 75.49 & 25.16 & 75.92 & 25.30 \\
\hline
\end{tabular}

$\mathrm{S} / \mathrm{N}$ ratio for number of tools used

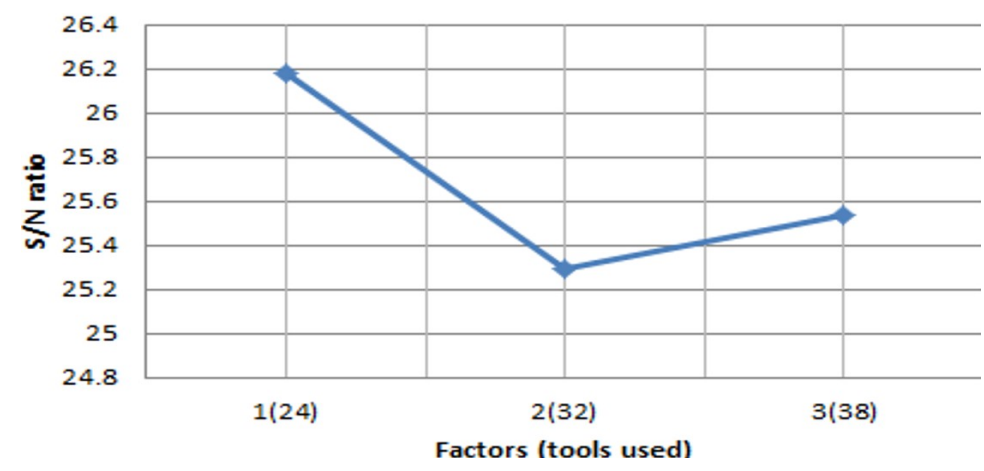

$\mathrm{S} / \mathrm{N}$ ratio for number of machines used

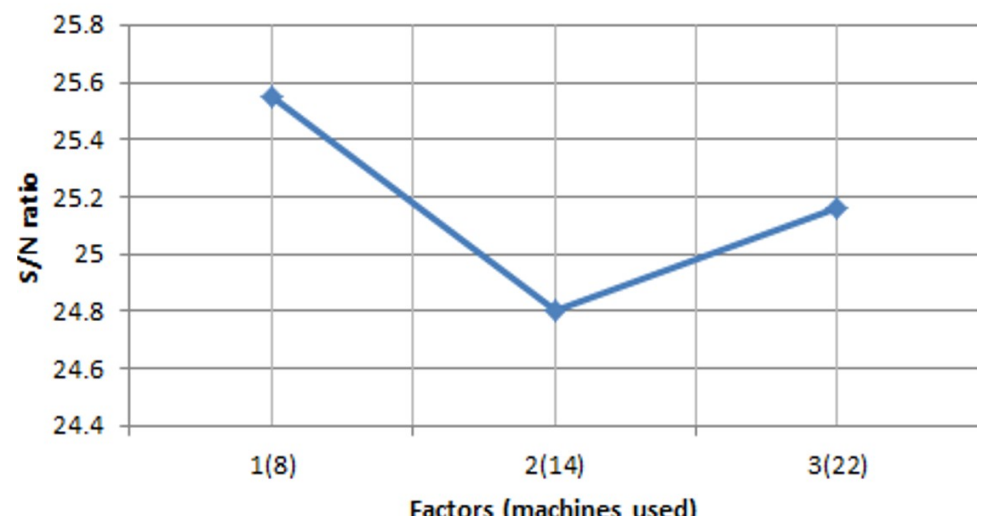

$\mathrm{S} / \mathrm{N}$ ratio for number of manufacturing cells

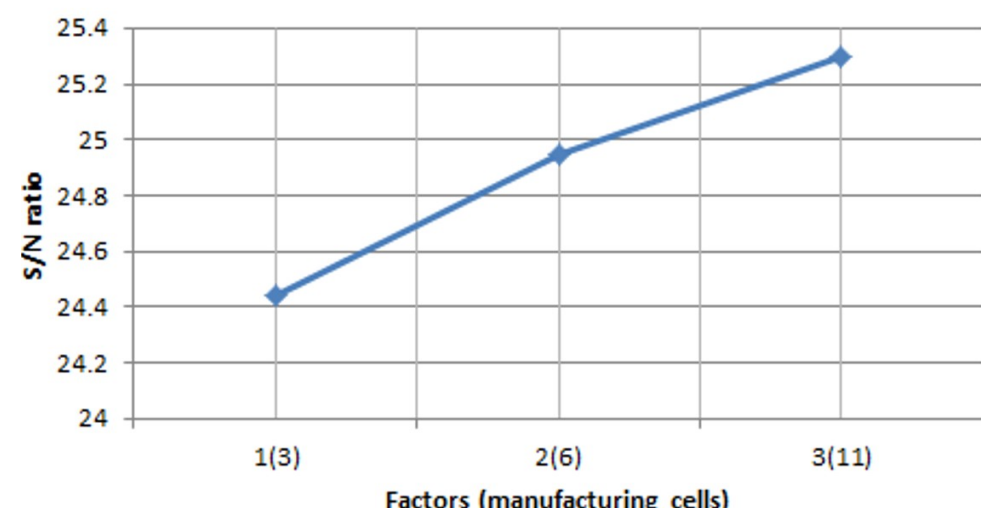

FIG. 4(a-c). SNR (PRODUCTIVITY) FOR THREE CONTROL FACTORS VS. THEIR THREE LEVELS 
Table 9 exhibits values of sum and average for all control variables and against their three distinct levels. Here the "noise" variable is dimensional accuracy and the criteria used was smaller the better. Graphical depiction through design experts is provided in Fig. 5 where data of SNR for control variables is plotted on $\mathrm{y}$ axis against levels on $\mathrm{x}-$ axis.

In Table 10, parameters variation analysis results are presented. We can conclude from the Table 9 that "machines" factor explains the variation in "productivity" by $39.5 \%$ which is the highest and next to it, tools explains it by $33.1 \%$. Similarly, error in "productivity" analysis is $3.4 \%$ which is less than the error value for dimensional accuracy (4.8\%). Variation explanation by percentage follows the same trend for "dimensional accuracy" as for productivity and it is accounted for by "machines" equal to $35.8 \%$ and "tools" factor explains it by $30.6 \%$.

Table 11 contains results of optimized analysis using Taguchi method. Since the idea was to maximize the productivity, we opted for larger the better criteria and accordingly, larger SNR value is 28.76 corresponding to arrangement in experiment 4 for which tools employed are 32 , machines in use equals 8 while there are 6 manufacturing cells.

Lastly in Table 12, optimized results of Taguchi method for "dimensional accuracy" are reported. Here, we chose smaller the better criteria and accordingly, smaller value of SNR is -6.82 which corresponds to second arrangement of experiment and tools employed are 24, machines used are 14 while manufacturing cells are 3 in number.

TABLE 8. SIGNIFICANCE LEVEL OF CONTROL FACTORS

\begin{tabular}{|c|c|c|}
\hline \multirow{2}{*}{ Productivity } & Factor & P-value \\
\hline \multirow{2}{*}{ Dimensional Accuracy } & Tools Employed & 0.04 \\
\cline { 2 - 3 } & Machines in Use & 0.019 \\
\cline { 2 - 4 } & Manufacturing Cells & 0.036 \\
\hline \multirow{2}{*}{\begin{tabular}{c}
$*$ \\
\cline { 2 - 3 }
\end{tabular}} & Tools Employed & 0.022 \\
\cline { 2 - 4 } & Machines in Use & 0.039 \\
\cline { 2 - 4 } & Manufacturing Cells & 0.005 \\
\hline
\end{tabular}

TABLE 9. SUM AND AVERAGE OF THREE LEVELS FOR CONTROL FACTORS

\begin{tabular}{|c|c|c|c|c|c|c|}
\hline \multirow{2}{*}{ Level } & \multicolumn{2}{|c|}{$\begin{array}{c}\text { Tools Employed } \\
\text { (tu) }\end{array}$} & Sum & Average & Sum & \multicolumn{2}{c|}{ Manufacturing Cells (dc) } \\
\cline { 2 - 7 } & -27.89 & -9.29 & -28.82 & -9.60 & -25.57 & Average \\
\hline 1 & -25.42 & -8.47 & -27.19 & -9.06 & -28.36 & -8.52 \\
\hline 2 & -28.16 & -9.39 & -29.32 & -9.77 & -29.49 & -9.45 \\
\hline 3 & & & & & \\
\hline
\end{tabular}

Mehran University Research Journal of Engineering \& Technology, Volume 38, No. 3, July, 2019 [p-ISSN: 0254-7821, e-ISSN: 2413-7219] 
$\mathrm{S} / \mathrm{N}$ ratio for number of tools used

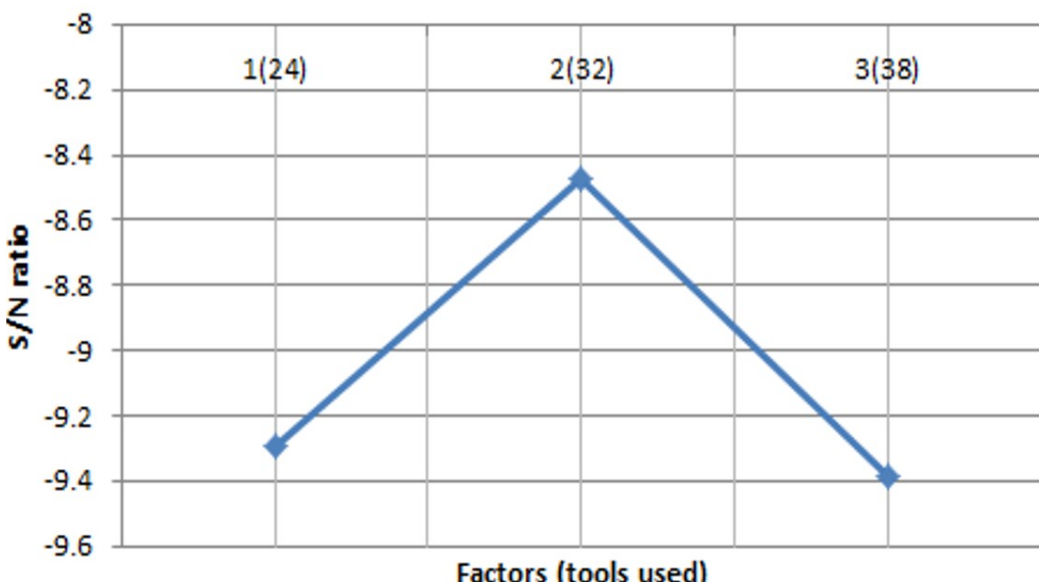

$\mathrm{S} / \mathrm{N}$ ratio for number of machines used

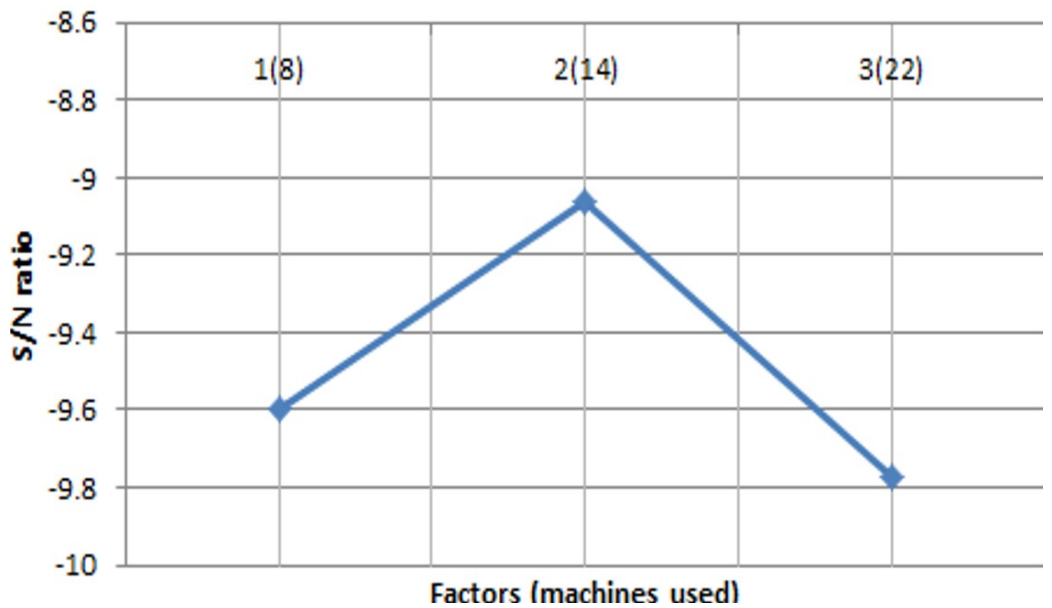

$\mathrm{S} / \mathrm{N}$ ratio for number of manufacturing cells

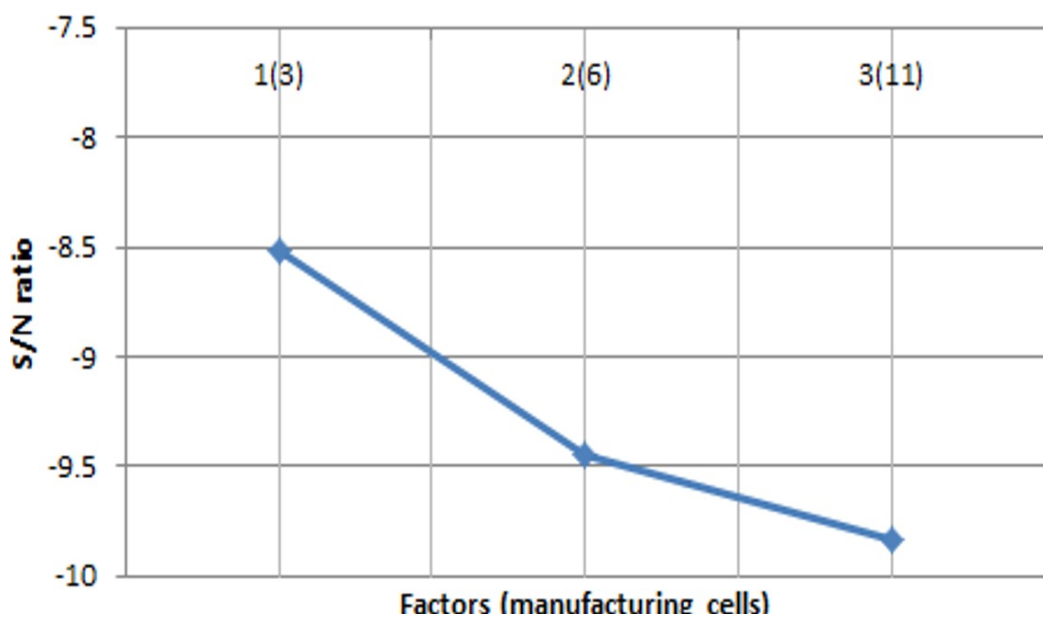

FIG. 5(a-c). SNR (DIMENSIONAL ACCURACY) FOR THREE CONTROL FACTORS VS. THEIR THREE LEVELS 


\section{DISCUSSION}

Reverse logistics starts with collection of EOL products from customer followed by subsequent recycling for energy extraction and introduction into secondary market [35]. There are two coping mechanisms for RL products; either they can be process through a dedicated production line or these products can be processed with the forward assembly line [36]. Allocation of dedicated production line can be quite costly and thus it is suggested that RL might be processed with the forward production for cost optimality and enhancement in performance [37]. In this study, we have considered combined framework of closed loop supply chain in which both forward and reverse production are being performed as shown in the framework (Fig. 6).

When forward production is assisted by reverse production, enterprises needs to re-evaluate their strategy as flexibility might be required in the resource mobilization [38]. There can be a compromise on the quality of production and productivity due to the dynamic induction of reverse products in manufacturing lines. Reverse logistics are reported to pose challenges of quality as such products have already completed their useful life [39] and right combination of resource mix can provide

TABLE 11. OPTIMIZED VALUES OF CONTROL FACTORS FOR "PRODUCTIVITY"

\begin{tabular}{|c|c|}
\hline Parameter & Optimal Value \\
\hline Tools Employed(tu) & 32 \\
\hline Machines in Use (m) & 8 \\
\hline Manufacturing Cells (dc) & 6 \\
\hline
\end{tabular}

TABLE 12. OPTIMIZED VALUES OF CONTROL FACTORS FOR "DIMENSIONAL ACCURACY"

\begin{tabular}{|c|c|}
\hline Parameter & Optimal Value \\
\hline Tools Employed (tu) & 24 \\
\hline Machines in Use (m) & 14 \\
\hline Manufacturing Cells (dc) & 3 \\
\hline
\end{tabular}

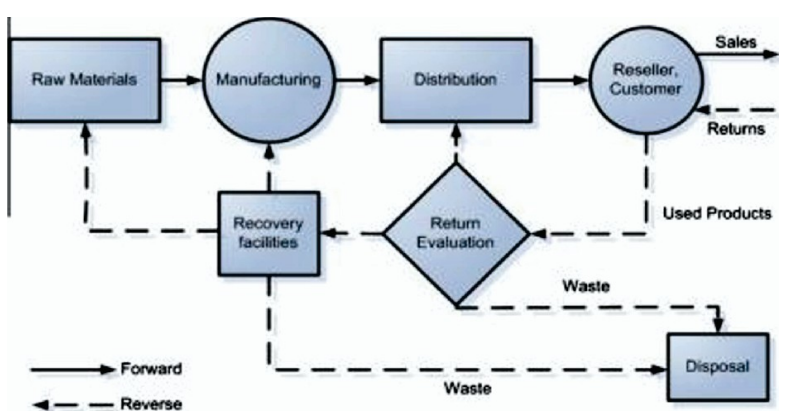

FIG. 6. PROCESS FLOW OF CLOSED LOOP SUPPLY CHAIN PRODUCTION

TABLE 10. ANOVA STATISTICS OF THE CONTROL FACTORS

\begin{tabular}{|c|c|c|c|c|c|}
\hline Parameter & S. Squares & Mean Square & F-Ratio & \multicolumn{3}{c|}{ Variation } \\
(\%)
\end{tabular}

Mehran University Research Journal of Engineering \& Technology, Volume 38, No. 3, July, 2019 [p-ISSN: 0254-7821, e-ISSN: 2413-7219] 
optimal results as accomplished in the current study. In competitive production environment, businesses tend to optimize on multiple fronts besides quality production and thus this study has two fold objectives of meeting quality and improving productivity.

As discussed in introduction section of this study, a follow up methodology was used to validate the experimental study findings. We employed MILP to evaluate the robustness of statistics. MILP tool was used considering cost as an input for tooling, machining \& number of manufacturing cells and cost of transportation between levels. Transportation cost is important in this analysis as different tools, machines and cells have different distances between them and hence variable transportation cost. The idea was to minimize total cost of production system and selection of optimal combination of tools, machines and cells. We assume that the production operates uninterruptedly until demand is fulfilled. Secondly, production demand (D) is considered to be equal to 150 Units. Nomenclature of index and parameters is provided in appendix. We have following mathematical cost optimization function;

Objective function

Minimize

$\mathrm{C}+\mathrm{Ctr}$

where $\mathrm{C}$ is overall production cost and $\mathrm{Ctr} \mathrm{S}$ Transportation cost and both are operationalized in Equations (2-3) as:

$$
\begin{aligned}
& C=\sum_{k=1}^{c e} \sum_{j=1}^{m} \sum_{i=1}^{t} C p+\sum_{i=1}^{t} t \cdot C t+\sum_{j=1}^{m} m \cdot C m+\sum_{k=1}^{c e} c e . C c e \\
& C t r=\sum_{i=1}^{t} C t, t+1 . d t, t+1+\sum_{j=1}^{m} C m, m+1 . d m, m+1+\sum_{k=1}^{c e} C c e, c e+1 . d c e, c e+1
\end{aligned}
$$

S.t;

$\mathrm{Ct}+\mathrm{Cp}+\mathrm{Cm} \leq \mathrm{C}$
$\mathrm{Ct}, \mathrm{t}+1+\mathrm{Cm} \mathrm{m}+1+\mathrm{Cce}, \mathrm{ce}+1 \leq \mathrm{Ctr}$

$\mathrm{t} \geq 0 ; \mathrm{m} \geq 0 ; \mathrm{Ce} \geq 0$

$\mathrm{p}(\mathrm{t}+\mathrm{m}+\mathrm{Ce}) \geq \mathrm{D}$

There are two segments of objective function. First section inculcates the overall production cost including cost of tooling, machining and manufacturing cells assignment. Second part considers the transportation cost between tools, machines and manufacturing cells. Constraints in the MILP functions are related to overall cost associated with production, limit on transportation cost, integrity of parameters and demand fulfilment criteria.Cost minimization was assessed for both productivity data (LTB criteria of design of experiments) and dimensional accuracy (STB criteria used in experimental design). LINGO 17.0software was used for data entry and MILP based validation. Different levels of tools, machines and cells were fed into the MILP model for cost comparison. Figs. 7-8 contains the modeling results for both productivity and accuracy analysis, respectively.For productivity parameter, cost indices for number of tools were equated to be US\$376, US\$301 andUS\$394 for tools number of 24, 32 and 38, respectively. Similarly, for combination of machines, cost indices were US\$530, US\$602 and US\$631 for 8, 14 and 22 number of machines, respectively. Lastly for number of manufacturing c ells, cost was equated to be equal to US\$1034 for 3 manufacturing cells, US\$780 for 6 manufacturing cells while US\$934 for number of dedicated manufacturing cells equal to 11 . Given cost values and Fig. 7 plots, we can conclude that level 2 tools, level 2 manufacturing cells value and level 1 value of machines provide with optimal cost results. The combination of tools, machines $\&$ cells are 32,8 and 6 respectively which is in line with the experimental design findings using orthogonal array mechanism. We can 
conclude that the combination of facilities for productivity is re-affirmed using two different approaches. An additional analysis was performed using MILP approach to compare overall production \& transportation cost between tools, machines \& manufacturing cells. Fig. 7 provides with an extra plot of overall production cost and transportation cost. On average, level 1 value of each dependent (control variable) results into an overall minimization of production as well as transportation cost.

Similarly, analysis based on mathematical optimization was performed for dimensional accuracy noise factor. Fig. 8 contains graphs for cost minimization function
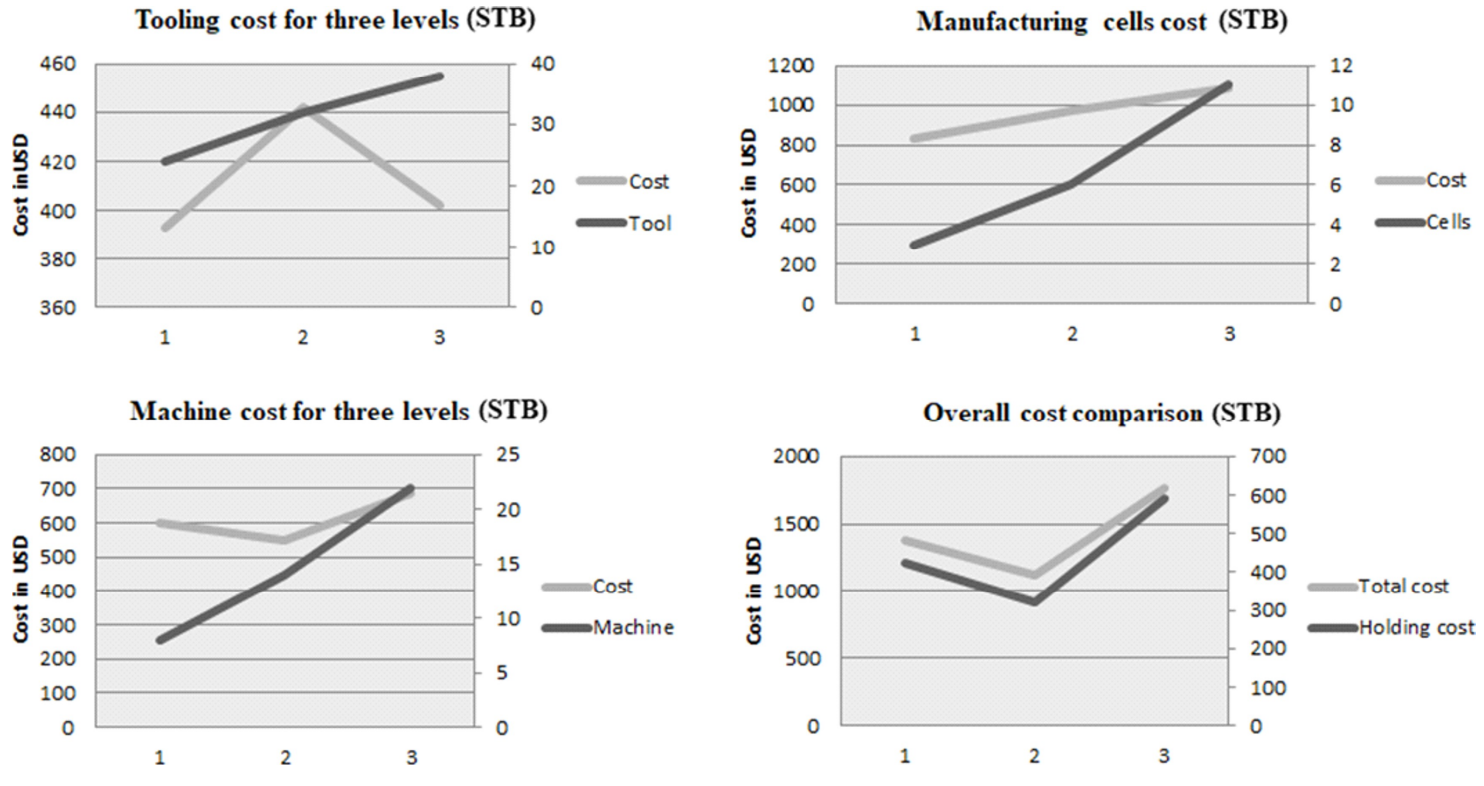

FIG. 7. COMPARISON OF MILP BASED COST INDICES FOR PRODUCTIVITY

Tooling cost for three levels (LTB)

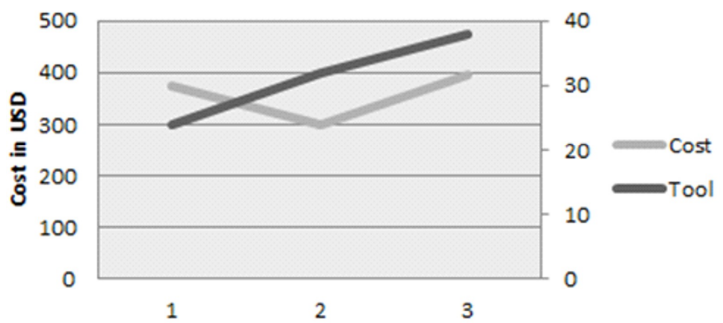

Machine cost for three levels (LTB)

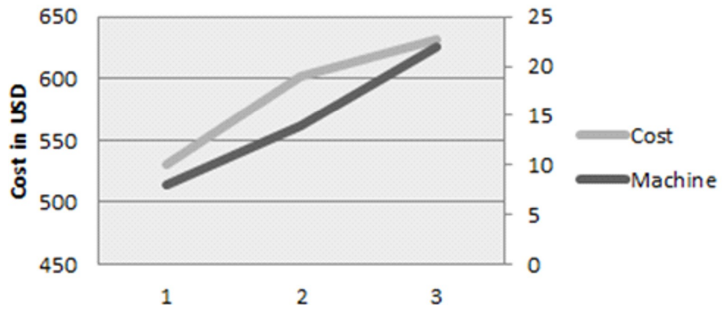

Manufacturing cells cost (LTB)

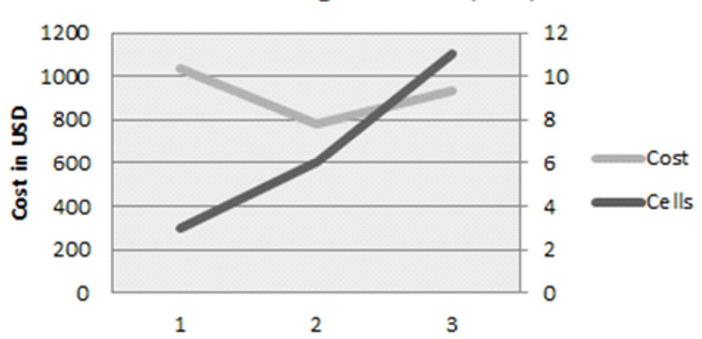

Overall cost comparison (LTB)

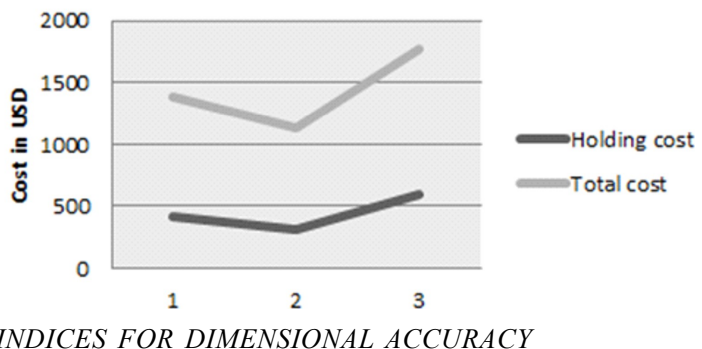

Mehran University Research Journal of Engineering \& Technology, Volume 38, No. 3, July, 2019 [p-ISSN: 0254-7821, e-ISSN: 2413-7219] 
for tools, machines and manufacturing cells. For tools level 1,2 and 3 corresponding to 24,32 and 38 number of tools, cost of production was estimated to be US\$393, US\$442 andUS\$402, respectively, Production cost of machines combination levels with values 1,2 and $3(8,14$ and 22 machines $)$ was equated to be equal to US\$602, US\$549 andUS\$686. Similarly, cost indices of US\$834, \$972 andUS\$1084 were attributed to manufacturing cells with values of 3, 6 and 11. MILP based analysis suggested level combination values for tools, machines \& manufacturing cells equal to 24,14 and 3 , respectively. These results were according to the experimental design findings and hence we can conclude that both methods yield similar findings for noise variables of productivity and dimensional accuracy. Lastly, on average level 2 combination of tools, machines and manufacturing cells results into an overall minimal production as well as transportation costs in the case of dimensional accuracy.

\section{CONCLUSION}

In this study, we have provided optimal assignment of control factors for two different conditions. In the first case, we have optimized (maximized) the productivity while in second case we optimize (minimize) dimensional variation in the product. Taguchi based experimentation can be used to further analyze and compare the results of forward and reverse logistics in separate context so that a global perspective of the phenomena can be built. Future work can focus on investigating the cost impact of both situations and its overall effect of profitability.

\section{NOMENCLATURE}

\section{Indexing}

$\mathrm{i} ; \mathrm{i} \in\{1,2 \ldots . . \mathrm{t}\}$; set of tools

$\mathrm{j} ; \mathrm{j} \in\{1,2 \ldots . \mathrm{m}\}$; set of machines

$\mathrm{k} ; \mathrm{k} \in\{1,2 \ldots . \mathrm{Ce}\}$ set of manufacturing cells

\section{Parameters}

$\mathrm{D}$ is production demand

$\mathrm{Cp}$ is cost of production

$\mathrm{Ct}$ is cost of tooling

$\mathrm{Cm}$ is machining cost

Cce is manufacturing cells cost

$\mathrm{t}$ is number of tools

$\mathrm{m}$ is number of machines

Ce is number of manufacturing cells

$\mathrm{p}$ is productivity

$\mathrm{C}^{\prime}$ is transportation cost

$\mathrm{C}$ is over cost

$\mathrm{dt}, \mathrm{t}+1$ is distance between consecutive tools

$\mathrm{dm}, \mathrm{m}+1$ is distance between consecutive machines

dce, ce +1 is distance between consecutive manufacturing cells

\section{ACKNNOWLEDGEMENT}

The author extends his gratitude to the anonymous reviewers for their kind inputs and suggestion to make this study worthwhile. Mr. Khawar Naeem, Assistant Professor, Department of Industrial Engineering, University of Engineering \& Technology, Peshawar, Pakistan, is also thanked for his valued contributions.

\section{REFERENCES}

[1] Tao, F., Cheng, Y., Zhang, L., and Nee, A.Y., “Advanced Manufacturing Systems: Socialization Characteristics and Trends", Journal of Intelligent Manufacturing, Volume 28, No. 5, pp. 1079-1094, 2017. 
[2] Tosarkani, B.M., and Amin, S.H., "A Possibilistic Solution to Configure a Battery Closed-Loop Supply Chain: MultiObjective Approach", Expert Systems with Applications, Volume 92, pp. 12-26, 2018.

[3] Paksoy, T., Bekta ${ }^{\circ}$, T., and Özceylan, E., “Operational and Environmental Performance Measures in a MultiProduct Closed-Loop Supply Chain", Transportation Research Part-E, Logistics and Transportation Review, Volume 47, No. 4, pp. 532-546, 2011.

[4] Kumar, N.R., and Kumar, R.S., "Closed Loop Supply Chain Management and Reverse Logistics-A Literature Review", International Journal of Engineering Research and Technology, Volume 6, No. 4, pp. 455-468, 2013.

Guide Jr, V.D.R., Jayaraman, V., and Linton, J.D., "Building Contingency Planning for Closed-Loop Supply Chains with Product Recovery", Journal of Operations Management, Volume 21, No. 3, pp. 259-279, 2003.

[6] Beamon, B.M., "Designing the Green Supply Chain", Logistics Information Management, Volume 12, No. 4, pp. 332-342, 1999.

[7] Tai, F.M., and Chuang, S.H., "Corporate Social Responsibility”, Ibusiness, Volume 6, No 3, pp. 117, 2014.

[8] Srivastava, S.K., "Green Supply Chain Management: A State of the Art Literature Review", International Journal of Management Reviews, Volume 9, No. 1, pp. 53-80, 2007.

[9] De Giovanni, P., Reddy, P.V., and Zaccour, G., "Incentive Strategies for an Optimal Recovery Program in a ClosedLoop Supply Chain”, European Journal of Operational Research, Volume 249, No. 2, pp. 605-617, 2016.

[10] Khor, K.S., and Udin, Z.M., "Impact of Reverse Logistics Product Disposition Towards Business Performance in Malaysian E\&E Companies", Journal of Supply Chain and Customer Relationship Management, 2012.

[11] Kolk, A., Rivera-Santos, M., and Rufin, C., "Reviewing a Decade of Research on the "Base/Bottom of the Pyramid" Concept", Business \& Society, Volume 53, No. 3, pp. 338-377, 2014.

[12] Wilson, D.C., Araba, A.O., Chinwah, K., and Cheeseman, C.R., "Building Recycling Rates through the Informal Sector", Waste Management, Volume 29, No. 2, pp. 629-635, 2009.
[13] Tibben-Lembke, R.S., "Life After Death: Reverse Logistics and the Product Life Cycle", International Journal of Physical Distribution and Logistics Management, Volume 32, No. 3, pp. 223-244, 2002.

[14] Tibben-Lembke, R.S., and Rogers, D.S., "Differences between Forward and Reverse Logistics in a Retail Environment: Supply Chain Management", An International Journal, Volume 7, No. 5, pp. 271-282, 2002 .

[15] Alshamsi, A., and Diabat, A., "A Reverse Logistics Network Design", Journal of Manufacturing Systems, Volume 37, pp. 589-598, 2015.

[16] Das, K., and Posinasetti, N.R.,"Addressing Environmental Concerns in Closed Loop Supply Chain Design and Planning”, International Journal of Production Economics, Volume 163, pp.34-47, 2015.

[17] Govindan, K., Soleimani, H., and Kannan, D., "Reverse Logistics and Closed-Loop Supply Chain: A Comprehensive Review to Explore the Future", European Journal of Operational Research, Volume 240, No. 3, pp. 603-626, 2015.

[18] Cannella, S., Bruccoleri, M., and Framinan, J.M., "Closed-Loop Supply Chains: What Reverse Logistics Factors Influence Performance?", International Journal of Production Economics, Volume 175, pp. 35-49, 2016.

[19] Sarkis, J., Helms, M.M., and Hervani, A.A., "Reverse Logistics and Social Sustainability", Corporate Social Responsibility and Environmental Management, Volume 17, No.6, pp. 337-354, 2010.

[20] Wang, J.J., Chen, H., Rogers, D.S., Ellram, L.M., and Grawe, S.J., "A Bibliometric Analysis of Reverse Logistics Research (1992-2015) and Opportunities for Future Research”, International Journal of Physical Distribution \& Logistics Management, Volume 47, No. 8, pp.666-687, 2017.

[21] Banasik, A., Kanellopoulos, A., Claassen, G.D.H., Bloemhof-Ruwaard, J.M., andVan der Vorst, J.G.,"Closing Loops in Agricultural Supply Chains Using MultiObjective Optimization: A Case Study of an Industrial Mushroom Supply Chain”, International Journal of Production Economics, Volume 183, pp. 409-420, 2017. 
[22] Paksoy, T., Bekta ${ }^{\circ}$, T., and Özceylan, E., “Operational and Environmental Performance Measures in a MultiProduct Closed-Loop Supply Chain”, Transportation Research Part-E: Logistics and Transportation Review, Volume 47, No. 4, pp. 532-546, 2011.

[23] Jayaram, J., and Avittathur, B., "Green Supply Chains: A Perspective from an Emerging Economy", International Journal of Production Economics, Volume 164, pp. 234-244, 2015.

[24] Zhou, W., and Piramuthu, S., "Remanufacturing with RFID Item-Level Information: Optimization, Waste Reduction and Quality Improvement", International Journal of Production Economics, Volume 145, No. 2, pp.647-657, 2013.

Chakraborty, K., Mondal, S., and Mukherjee, K., "A Study on Remanufacturing Possibility of a Product", Microsystem Technologies, pp. 1-6, 2017.

Zhu, Q., Li, H., Zhao, S., and Lun, V., "Redesign of Service Modes for Remanufactured Products and its Financial Benefits", International Journal of Production Economics, Volume 171, pp. 231-240, 2016.

Turrisi, M., Bruccoleri, M., and Cannella, S., "Impact of Reverse Logistics on Supply Chain Performance", International Journal of Physical Distribution \& Logistics Management, Volume 43, No. 7, pp. 564-585, 2013.

Safari, F.M., and Omidvari, M., "Effect of Green Supply Chain Management on Production Costs, Quality and Productivity Using Structural Equation Modeling", International Journal of Industrial and Systems Engineering, Volume 27, No. 3, pp. 427-441, 2017.

Mahfouz, A., Hassan, S.A., and Arisha, A., "Practical Simulation Application: Evaluation of Process Control Parameters in Twisted-Pair Cables Manufacturing System", Simulation Modelling Practice and Theory, Volume 18, No. 5, pp. 471-482, 2010.

Paydar, M.M., and Olfati, M., "Designing and Solving a Reverse Logistics Network for Polyethylene Terephthalate Bottles", Journal of Cleaner Production, 2018 .
[31] Fattahi, M., and Govindan, K., "Integrated Forward/ Reverse Logistics Network Design Under Uncertainty with Pricing for Collection of Used Products", Annals of Operations Research, Volume 253, No.1, pp. 193-225, 2017.

[32] Rabbani, M., Saravi, N.A., and Farrokhi-Asl, H., "Design of a Forward/Reverse Logistics Network with Environmental Considerations", International Journal of Supply and Operations Management, Volume 4, No. 2, pp. 115-132, 2017.

[33] Li, J.Q., Wang, J.D., Pan, Q.K., Duan, P.Y., Sang, H.Y., Gao, K.Z., and Xue, Y., "A Hybrid Artificial Bee Colony for Optimizing a Reverse Logistics Network System”, Soft Computing, Volume 21, No. 20, pp. 6001-6018, 2017.

[34] Athreya, S., and Venkatesh, Y.D., "Application of Taguchi Method for Optimization of Process Parameters in Improving the Surface Roughness of Lathe Facing Operation", International Refereed Journal of Engineering Science, Volume 1, No. 3, pp. 13-19, 2012.

[35] Govindan, K., Soleimani, H., and Kannan, D., "Reverse Logistics and Closed-Loop Supply Chain: A Comprehensive Review to Explore the Future", European Journal of Operational Research, Volume 240, No. 3, pp. 603-626, 2015.

[36] Sasikumar, P., and Kannan, G., "Issues in Reverse Supply Chain, Part-III: Classification and Simple Analysis", International Journal of Sustainable Engineering, Volume 2, No.1, pp.2-27, 2009.

[37] Mutha, A., and Pokharel, S., "Strategic Network Design for Reverse Logistics and Remanufacturing Using New and Old Product Modules", Computers \& Industrial Engineering, Volume 56, No. 1, pp. 334-346, 2009.

[38] Pedram, A., Yusoff, N.B., Udoncy, O.E., Mahat, A.B., Pedram, P., and Babalola, A., "Integrated Forward and Reverse Supply Chain: A Tire Case Study”, Waste Management, Volume 60, pp. 460-470, 2017.

[39] Das, K., and Chowdhury, A.H., "Designing a Reverse Logistics Network for Optimal Collection, Recovery and Quality-Based Product-Mix Planning”, International Journal of Production Economics, Volume 135, No. 1, pp. 209-221, 2012. 